\title{
AS CONTRIBUIÇÕES PARA A FANFARRA DA ESCOLA ESTADUAL GIRASSOL DE TEMPO INTEGRAL AGRÍCOLA DAVID AIRES FRANÇA PELO PROGRAMA RESIDÊNCIA PEDAGÓGICA DA UFT/ARRAIAS
}

Contributions to the fanfarra of the State School of Sunday agricultural David Aires

França for the pedagogical Residence Program of UFT/ Arraias

Contribuciones a la fanfarra de la Escuela Estatal Girasol Agrícola a Tiempo

Completo David Aires Francia por el Programa de Residencia Pedagógica

UFT/Arraias

Aparecida de Jesus Soares Pereira ${ }^{* 1}$, Waldir Pereira da Silva ${ }^{1}$, Maristela Firmino da Cunha Gomes $^{1}$, José Bomfim dos Santos ${ }^{1}$

${ }^{1}$ Laboratório de Educação Musical, Curso de Licenciatura em Educação do Campo, Universidade Federal do Tocantins-UFT, Arraias -TO, Brasil.

*Correspondência: Curso de Licenciatura em Educação do Campo, Universidade Federal do Tocantins - UFT, Campus Professor Dr. Sérgio Jacintho Leonor, Av. Juraíldes de Sena e Abreu, Setor Buritizinho/ sala 10 - Bloco Bala, Arraias - Tocantins, Brasil.CEP:77.330-000.e-mails: cida.soares@uft.edu.br

\section{Artigo recebido em 03/04/2020 aprovado em 09/04/2020 publicado em 17/04/2020.}

\section{INTRODUÇÃO}

O presente trabalho tem como objetivo fazer um relato das experiências como residente do Programa Residência Pedagógica - PRP do Curso de Licenciatura em Educação do Campo - Códigos e Linguagens Artes Visuais e Música da Universidade Federal do Tocantins em Arraias, destacando os desafios enfrentados para se concretizar o ensino da música nas escolas de Educação Básica, destacando também as experiências vivenciadas no processo de reorganização e reativação da fanfarra da Escola parceira no RP.

Entende-se que este contato com o ambiente escolar torna-se essencial no processo de formação docente e no aperfeiçoamento das experiências profissionais, como também no desenvolvimento das habilidades no meio escolar.

O PRP é uma das ações que integram a Política Nacional de Formação de Professores e tem por objetivo induzir o aperfeiçoamento da formação prática nos cursos de Licenciatura, promovendo a imersão do licenciando na escola de Educação Básica (CAPES, 2019). Tendo em vista o aperfeiçoamento do Estágio Escolar, experimentando situações concretas do cotidiano escolar e da sala de aula em consonância com o Estágio, o Residência Pedagógica proporciona uma interação entre o residente e as escolas da rede pública, mostrando a importância da construção do processo ensino - aprendizagem através da educação musical. Um dos aspectos foi proporcionar ao aluno a oportunidade de descobrir ou redescobrir o mundo sonoro, à medida que toma consciência dele ao seu redor, procurando integrar-se através do desenvolvimento da expressão musical, também desenvolver as potencialidades musicais do educando, respeitando a assimilação natural de suas faculdades e perceber os elementos musicais em atividades de apreciação musical através da voz, corpo, materiais sonoros, brincadeiras, jogos e notações musicais. Para Souza (2000, p. 176), “a tarefa básica da música na 
educação é fazer contato, promover experiências com possibilidades de expressão musical e introduzir os conteúdos e as diversas funções da música na sociedade, sob condições atuais e históricas.”. Desta forma, o PRP, proporciona o movimento teórico de compreensão do trabalho docente.

\section{METODOLOGIAS E MATERIAIS}

O trabalho desenvolvido no Residência Pedagógica começou com a caracterização da Escola, observando a sua estrutura física, conhecendo o Projeto Político Pedagógico, análise da proposta curricular e conteúdos determinados pela SEDUC TO, conversa com os professores, reunião com os alunos.

A Escola Estadual Girassol de Tempo Integral Agrícola David Aires França se localiza na rodovia Arraias/Campos Belos KM 07 Zona Rural. A sua infraestrutura é bastante ampla na qual promove uma educação de qualidade, proporciona um ambiente físico em que os alunos ficam estimulados, viabilizando o aprendizado, além de favorecer aos alunos a conclusão do Ensino Médio com uma certificação em Técnico - Agropecuária.

Ao analisar a proposta curricular foi possível perceber as angústias e preocupações dos professores, tendo em vista que a Unidade Escolar abriga alunos de várias regiões do país apresentando uma diversidade cultural bastante forte, sendo $99 \%$ de sua clientela oriunda da cultura negra, devido a Escola estar localizada próxima aos grandes grupos quilombolas (Tocantins e Goiás). Sendo assim, os professores buscam adequar e trabalhar conteúdos que mais aproximam as suas realidades, sempre enfatizando a cultura negra.

As atividades práticas com a fanfarra iniciouse com um trabalho coletivo entre residentes e alunos da escola no sentido de recuperarem os instrumentos musicais que não se encontravam em condições de serem utilizados. A partir deste trabalho iniciaram-se as atividades didático-pedagógicas com o estudo teórico-prático de diversos ritmos que seriam utilizados em um repertório específico para as solenidades cívicas.

Diante da realidade encontrada na escola no que diz respeito à manutenção da fanfarra percebe-se certo distanciamento dos órgãos superiores com a realidade desta Unidade Escolar. No que diz respeito a Educação Musical, percebe-se que ainda não há uma formação específica por parte dos professores da Educação Básica na escola o que dificulta a permanência contínua da fanfarra.

Como a escola possui instrumentos de fanfarra facilitou a organização e o processo das atividades de ensino. O objetivo inicial foi a aprendizagem musical e a inclusão social. Segundo Cislaghi (2009),

\footnotetext{
além da influência na continuidade da cultura, as bandas e fanfarras exercem uma função de inclusão social, permitindo afastar crianças e jovens da marginalidade social e possibilitando além da possível profissionalização, uma melhora na qualidade de vida das crianças e jovens atendidos (CISLAGHI, 2009, p.19).
}

Uma atividade musical complementar para uma escola de tempo integral. A contribuição foi para todos, pois foi uma oportunidade de troca de informações e experiências entre o instrutor, bem como de absorção de novos conteúdos, principalmente teóricos aos participantes que apresentavam menos conhecimentos em relação à prática com Fanfarra. Assim, os participantes da Fanfarra ensaiaram para o desfile cívico de 07 de setembro de 2019 podendo participar juntamente com a comunidade escolar das comemorações do Desfile em Arraias-TO, como também as diversas atividades da Escola, e também para o II Seminário do Residência Pedagógica que aconteceu em 23 novembro de 2019 na UFT em Arraias. 


\section{RESULTADOS E DISCUSSÃO}

Verifica-se que o PRP fortaleceu e colaborou no aperfeiçoamento do desenvolvimento do processo de formação docente voltadas para a Educação do/no Campo utilizando os instrumentos musicais da fanfarra, aplicando-os no processo de Educação Musical, objetivando também a participação em solenidades oficiais da escola assim como em solenidades cívicas. Esta prática permitiu aos futuros docentes vivenciarem e lidarem com situações e desafios que a práxis pedagógica nos apresenta.

\section{CONCLUSÃO}

O programa de residência pedagógica vem buscando o aprimoramento da formação docente por meio da necessária articulação entre o que os alunos aprendem na universidade e o que experimentam na prática do residência, considerando que justamente um dos aspectos mais importantes em relação à formação docente é proporcionar ao aluno oportunidades para que desenvolva a capacidade de relacionar teoria e prática docente. Vários autores já destacaram a necessidade de que o professor reflita sobre sua experiência, considerando que apenas informações não garantem experiência, como: (BONDÍA, 2001; PERRENOUD, 2002; NÓVOA, 1992). Ao longo do Programa Residência percebeu-se que foi possível empregar o conhecimento adquirido no curso. Foi também no RP que pôde-se desvelar a verdadeira vocação de ser professor. Ficou evidente também que uma educação de qualidade não depende somente do educador, mas de toda uma esfera conjunta que integra o processo educacional.

\section{AGRADECIMENTOS}

À CAPES pelo incentivo financeiro. À UFT por tornar possível a realização do Programa Residência Pedagógica. Ao Curso de Licenciatura em Educação do Campo da UFT - Artes Visuais e Música. Às
Escolas parceiras e todos que contribuíram para a realização dessa ação.

Todos os autores declararam não haver qualquer potencial conflito de interesses referente a este artigo.

\section{REFERÊNCIAS}

BONDÍA, J. L. Notas sobre a experiência e o saber de experiência. Disponível em: http://www.anped.org.br/rbe/rbedigital/RBDE19/RB DE19_04_JORGE_LARROSA_BONDI A.pdf (acesso em 15/4/2013).

CISLAGHI, Mauro César. Concepções e ações de educação Musical no projeto de bandas e fanfarras de São José - SC: três estudos de caso. 2009. Dissertação (Mestrado em Música) -Centro de Artes, Universidade do Estado de Santa Catarina, 2009.

COORDENAÇÃO DE APERFEIÇOAMENTO DE PESSOAL DE NÍVEL SUPERIOR - CAPES. Programa de Residência Pedagógica. Disponível em: https://www.capes.gov.br/educacaobasica/programa-residencia-pedagogica. Acesso em 21 de outubro de 2019.

NÓVOA, A. Formação de professores e profissão docente. Disponível em: http://repositorio.ul.pt/handle/10451/4758 (acesso em 10/4/2013).

PERRENOUD, P. A prática reflexiva no ofício de professor: profissionalização e razão pedagógica. Porto Alegre: Artmed, 2002.

SOUZA, Jusamara (Org.). Música, Cotidiano e Educação. Porto Alegre: Programa de Pós graduação em música da UFRGS, 2000. 